\title{
Impact of Training and Goal Setting on Employee Engagement and Commitment in Banking Sector of Pakistan
}

\author{
Amir Ali Khushk ${ }^{1}$, Zhang Zengtian ${ }^{2}$, Mavis Amoah ${ }^{3}$, Grace ${ }^{4}$ \\ ${ }^{1}$ University of Science and Technology China. ORCID: https://orcid.org/0000-0002-1895-9821 \\ Email: amir65378@gmail.com \\ 2 University of Science and Technology China. Email: zhzt@ustc.edu.cn \\ 3University of Science and Technology China. Email: mavisamoah93@ gmail.com \\ 4 University of Science and Technology China. Email: Ingrace2020@mail.ustc.edu.cn
}

\begin{tabular}{|c|c|}
\hline Article Info & Abstract \\
\hline Article history: & Purpose: This study aimed to explore the effect of training and goal setting on \\
\hline Received:15 June 2021 & employee engagement and commitment in the banking sectors of Hyderabad, \\
\hline Revised: 19 August 2021 & Pakistan. \\
\hline Accepted: 24 August 2021 & $\begin{array}{l}\text { Approach/Methodology/Design: The collection of information was acquired } \\
\text { using a closed-ended questionnaire with a Likert scale. The convenience }\end{array}$ \\
\hline Keywords: & $\begin{array}{l}\text { sampling method was used, and } 270 \text { respondents participated in the survey. } \\
\text { The data was analyzed by using Statistical Package for Social Sciences }\end{array}$ \\
\hline Training, Motivation & $(S P S S)$ \\
\hline Goal Setting & Findings: The findings revealed that training and goal setting can boost \\
\hline Employee commitment & employees' engagement and commitment in the banking sectors of \\
\hline Turnover & Hyderabad, Pakistan. \\
\hline Performance & $\begin{array}{l}\text { Practical Implications: The suggested model in the study can be executed in } \\
\text { almost any organization to increase the overall engagement and commitment }\end{array}$ \\
\hline JEL: M15,M20 & $\begin{array}{l}\text { of employees. For the model to be implemented effectively, a decent time has } \\
\text { to be devoted to the goal settings, as it is the most integral and critical phase }\end{array}$ \\
\hline Paper Type : & towards this whole organizational system. Each factor in this theoretical \\
\hline Research Article & $\begin{array}{l}\text { framework must also give as much information as needed to collaborate on it } \\
\text { to achieve the goal of organization. This model can be used, in specific, in the }\end{array}$ \\
\hline $\begin{array}{l}\text { Corresponding Author: } \\
\text { Zhang Zengtian }\end{array}$ & $\begin{array}{l}\text { services industry, to achieve their ultimate strategic goals. } \\
\text { Originality/value: This research provides empirical support for developing } \\
\text { management programs that promote employee training and goal setting, }\end{array}$ \\
\hline $\begin{array}{l}\text { Email: } \\
\text { zhzt@ustc.edu.cn }\end{array}$ & $\begin{array}{l}\text { leading to employee engagement and commitment. This study is important for } \\
\text { academia, professionals, and scholars alike. }\end{array}$ \\
\hline
\end{tabular}

\section{Introduction}

The banking sector is the most vital aspect of Pakistan's financial services. Banking sectors compete with one another to maximize profits. The changing outlook of the work situation owing to the technological progress makes the organizations face several problems to remain capable and to produce skilled and devoted personnel to realize the organization's objectives (Zahra et al., 2014). Organizations that struggle to attract and retain skilled people also struggle to increase efficiency in achieving goals. Increased employee performance in any firm, therefore, relies on the efforts made by the organization in the formation of dedicated personnel. Employee involvement in firms nowadays is seen as the main concern since it minimizes adverse behaviour, including stress, lateness, absenteeism and turnover. As a result, employers should be aware of all the aspects that play a vital role or have a significant impact on increasing employees' commitment (Irefin \& Mechanic, 2014; Shahid \& Azhar, 2013). 
Training is a type of engagement in which organizations engage their personnel to develop their skills, understanding, and competencies that aid in the completion of different tasks. The process in organizational performance can increase employees' dedication to their jobs (Alamri \& Alduhaim, 2017; R. Anitha \& Kumar, 2016). Almost every company provides training to its staff based on the demands of the company (Martin, 2010). Training requirement analysis can be done using a variety of approaches such as surveys, questionnaires, and observations, which help to identify areas that require training. Implementing training programs for employee development will boost employees' loyalty and dedication to the firm (Nkosi, 2015; Zehra, 2015). Businesses benefit from training because it allows them to develop a more efficient and skilled workforce. Training initiatives and goal setting can create stronger employee engagement and commitment by allowing workers to advance professionally. Goal setting has been the most significant aspect in increasing organizational commitment since it has a positive effect on employee commitment, it has a favorable impact on employee performance at a job (Knight et al., 2001). Further, it is not only significant in human resource management, but it has also been applied in other sectors of the management such as quality management, performance appraisal, and management program optimization (Ashraf et al., 2012).

After reviewing the previous literature, it can be concluded that setting goals boosts employee job engagement and commitment. Employee engagement refers to an employee working beyond the scope of his or her job. Worker desire to voluntarily bind with a company is another term for the engaged employee (Gubman, 2004). Several studies on employee engagement have already been conducted (Sendawula et al., 2018; Siddiqui \& Sahar, 2019). According to several credible reports, approximately 1100 articles could be easily reached via online research (Osborne \& Hammoud, 2017). Hence, by defining clear goals for employee satisfaction, you will be able to quickly attain improved work engagement (Mishra et al., 2014). This research will contribute to the management of people. Essentially, the purpose of our research is to emphasize the aspects that have not been addressed in earlier studies. While this study describes how an organization can improve organizational commitment by utilizing several mediating elements, previous studies have focused solely on individual or team achievement by utilizing various objectives, boosting engagement, and employee work enthusiasm (Medlin \& Green, 2009). This study focuses mainly on the impact of training and goal-setting on employees' engagement in the banking sector in Pakistan.

The training of employees may influence the development of a number of professional skills, experience and expertise which are essential to a worker's particular tasks at work. As a result, supervisors should view training and goal setting as vital tools for developing engaged and committed employees. Ultimately, this study concludes that if staff members achieve the desired set of skills via training and support in goal setting, they will take into account their commitment aimed at providing desired behaviours via engagement toward the organization's goals. By training and setting goals, not only will the workers' commitment boost, but it would also contribute to a high performance, efficiency and promising market share.

The conceptual model of this hypothesis is based on Social Exchange Theory (SET), which is illustrated in the theoretical framework. As per SET people form relationships through a series of mutual exchanges, resulting in a set of shared responsibilities for each group. Such 
relationships of social exchange are essentially characterized by mutual expectation among the parties involved (Eisenberger et al., 2001; Masterson et al., 2000). Therefore, the action of an individual contributes to an answer by the other. The recipient is forced to behave in kind if a person provides an advantage. In addition, this operation is considered as an exchange process with effective interactions frequently leading to feelings of engagement between stakeholders (Cropanzano \& Mitchell, 2005).

\section{Literature Review}

\section{Training}

In recent times, training programs have received significant attention in the scientific literature for both professionals and scholars in both the public and private sectors. Managers in general care about it, because most firms see training as an essential personnel investment. It is a process of improving the skills, perception and awareness of certain activities. Workers are empowered to conceive of new ways to do their jobs at workplace through training programs (Alamri \& Alduhaim, 2017). Training does not include only once training an employee but also constantly increasing the employee's abilities in response to variations so that he can make such organizational change. Training is regarded the most significant aspect in the present scenario if only because it aims to strengthen the performance of the company, but it also encourages participants to grow. The success of employees may rely on several aspects but "training" is perhaps the most significant aspect (Ali et al., 2021; Khushk, 2020; Muhammad \& Tanveer, 2015). Despite the growth in the investment in training, companies are quite afraid that trained staff will be lost to the competition and the amount of useful funds may be wasted (Mello, 2015). Because such, HR leaders must explain more than ever before the true worth of training for corporate senior managers with consideration of the impact on behaviour and attitudinal outcomes (e.g. enhanced work handling or increased employment performance). The analysis of the links between training and organizational results is a critical area of research in favor of HRD leaders and professionals' attempts to develop effective training settings (Ehrhardt et al., 2011). Even though it is quite expensive, training and development offers significant benefit in terms of increasing the capabilities of its personnel. Employees' training has a significant influence on workers' performance, which eventually increases their profitability (Newman et al., 2011; Sultana et al., 2012). Several studies have shown that training has a major impact on employee organizational commitment (Al-Emadi \& Marquardt, 2007; Bulut \& Culha, 2010; Hanaysha, 2016).

\section{Goal Setting}

The research contains a wide spectrum of discourse about diverse theoretical models of goal setting, optimism at the workplace, and employee commitment, although these factors have indeed been employed for various objectives (Knight et al., 2001). To understand the effects of motivation on employee productivity, the major aspect of our theory of targeting has previously been highlighted. Following on, the target was also ignored as the additional component of measuring performance and used to construct the organization's performance process. Many researchers have done an excellent job particularly for employee participation covering various facets of employee commitment and approaches to enhance workplace engagement (McBain, 
2007; Shaver, 2008). The organization's goals have a huge effect and a substantial positive relationship to organizational engagement, which can lead to an improvement in organizational commitment if the goals are well planned and executed The foundation on which this process begins is the goal establishing phase. If workers are encouraged with the target setting, the goalsetting must be performed as per the objectives and remedies accessible to achieve the particular task, and the organization commitment must be strengthened (Ashraf et al., 2012; Presslee et al., 2013). The establishing of goals is also important for productivity, since it does not conform to or correspond to the target, therefore performance also has an impact (Webb et al., 2010).

\section{Employee Engagement and Commitment}

Early work has been extended by Deci and Ryan (1985), distinguishing between internal and foreign motivations. Psychological ability and flexibility drive the person to develop behaviors that are vital for his/her physical and mental wellbeing and can lead to optimum growth and progress if fulfilled. Employee engagement is important to the success of any firm. In 1985, Deci and Ryan conducted the most notable study on employee engagement (Berens, 2013). The essential requirements of satisfaction are linked directly to employee commitment. A committed and significant job allows the employees to understand how valuable they are and how to engage them (Vandenabeele, 2014). Bolman \& Deal (2014) state that workers' autonomy is available when self-determination theory is used and workers can also have an impact on their environment. This interest goes beyond the advantages of intrinsic incentives. Significant work will promote employee engagement; it will not ensure that the worker is involved. To establish employee commitment, there is a requirement for freedom, intrinsic motivation, and influence. According to (La Guardia, 2009), psychological requirements produce a feeling of identity growth through internal motivation, resulting in the outcomes of commitment and engagement. Using potentials and commitment can impact a person's attitude, conduct, and aspirations, which are all positive components in a particular personality. The links between internal motivation and flow emotions were established by (Fullagar \& Mills, 2008). Flow is the comprehensive feeling when an employee is completely engaged in work.

Assessment of populations concerning the engagement of employees offers knowledge of demographic trends within the current workforce (Buttner et al., 2012). Corporate leaders can attract fresh graduates by financial compensation. Younger employees leave their organizations due to a lack of monetary reward, even though the activity meets their needs and desires (Butler et al., 2014). Millennials are much less devoted to their employers and are unwilling to make for their profession (Festing \& Schäfer, 2014). Baby Boomers are even less likely to be financially rewarded but more inclined to systems and organizational commitment (Saber, 2013). Corporate leaders can attract Baby Boomer generation through the projected organization a long term deal Millennials are far more inclined to sell in the absence of advancement or pay rises in a business Consequently, human resources professionals can be used effectively by terminating a Millennium rather than just a Baby Boomer while evaluating termination or departmental methods (Hayes, 2015). 


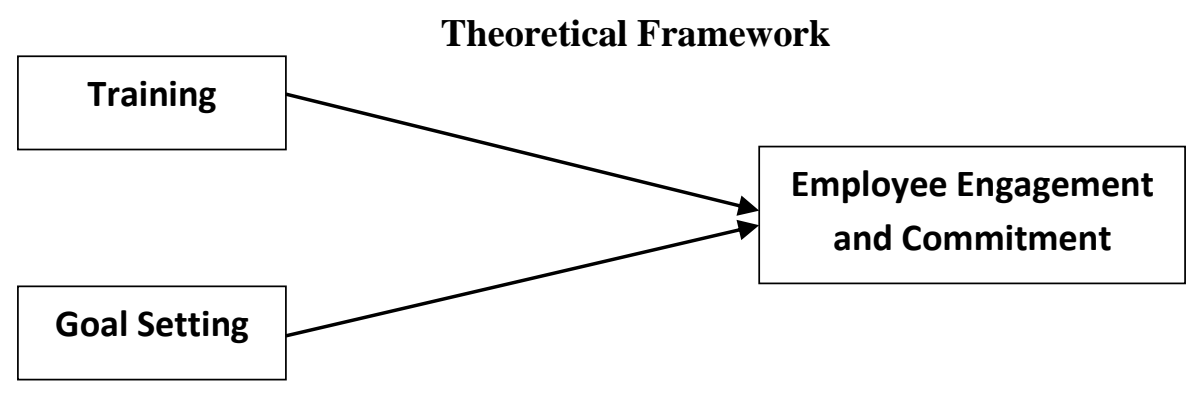

\section{Methodology and Procedures}

For this research, the primary data is obtained. The information was acquired using a structured questionnaire survey of a Likert scale. The survey has 36 closed-ended questions for each variable being investigated in this research.

\section{Research Instrument}

To evaluate the effect of training, the researcher used questionnaires from the study's scale (Hazra et al., 2017). It consists of 10 items on a Likert 5-point scale. The researchers adopted a questionnaire from a researcher's scale to measure goals (Nies et al., 2001) It contains 6 questions on a Likert 5-point scale. To evaluate the impact of employee engagement, the questionnaire was adopted by the researchers (Avery et al., 2007). It consists of 12 queries that are graded on a five-point Likert scale. To measure the commitment of employees, a questionnaire from the research has been adopted (Mowday et al., 1979). The report contains 8 items on a 5-point Likert scale.

\section{Population and Sample Size}

The study's population focuses on employees from the banking sector in Hyderabad, Pakistan. Staff members of Habib Bank Limited, Bank Al-Habib, Bank Alfalah, Silk Bank, Meezan Bank, and their branches in Hyderabad city are used as the survey's population. The convenience sampling technique was used in selecting respondents. The possible explanation for using this technique would be that replies were gathered based on the respondents' accessibility. This also aids in the collection of as many responses as possible, which aids in the final analysis. The sample size is determined to be 270 .

\section{Results and Discussion}

Demographic data frequencies

Gender

\begin{tabular}{lllll}
\hline Gender & Frequency & Percent & Valid percent & Cumulative percent \\
\hline Male & 180 & 66.67 & 66.67 & 66.47 \\
Female & 90 & 33.33 & 33.33 & 100.0 \\
Total & $\mathbf{2 7 0}$ & $\mathbf{1 0 0 . 0}$ & & \\
\hline
\end{tabular}

The survey received responses from 270 people. The survey had $66.67 \%$ male participants and $33.7 \%$ female participants.

Age

\begin{tabular}{ccccc}
\hline Age & Frequency & Percent & Valid percent & $\begin{array}{c}\text { Cumulative } \\
\text { percent }\end{array}$ \\
\hline $\mathbf{2 0 - 2 9}$ & 69 & 25.56 & 25.56 & 25.56
\end{tabular}




\begin{tabular}{ccccc}
$\mathbf{3 0 - 3 9}$ & 115 & 42.59 & 42.59 & 68.15 \\
$\mathbf{4 0 - 4 9}$ & 62 & 22.96 & 22.96 & 91.11 \\
$\mathbf{5 0}$ and above & 24 & 8.89 & 8.89 & 100.0 \\
Total & $\mathbf{2 7 0}$ & $\mathbf{1 0 0 . 0}$ & $\mathbf{1 0 0 . 0}$ & \\
\hline
\end{tabular}

Respondents were divided into four age groups: $30-39$ years old (42.59\%), 20-29 years old (25.56\%), 40 49 years old $(22.96 \%)$, and 50 and older ( $8.89 \%)$.

Education

\begin{tabular}{ccccc}
\hline Education & Frequency & Percent & Valid Percent & $\begin{array}{c}\text { Cumulative } \\
\text { percent }\end{array}$ \\
\hline Bachelors & 99 & 36.67 & 36.67 & 36.67 \\
Masters & 171 & 63.33 & 63.33 & 100.0 \\
Total & $\mathbf{2 7 0}$ & $\mathbf{1 0 0 . 0}$ & $\mathbf{1 0 0 . 0}$ & \\
\hline
\end{tabular}

The majority of the participants (63.33\%) managed to hold master's degree, while (38.1\%) accomplished their bachelor's degree.

\section{Banks}

\begin{tabular}{ccccc}
\hline Bank & Frequency & Percent & Valid percent & $\begin{array}{c}\text { Cumulative } \\
\text { percent }\end{array}$ \\
\hline HBL & 85 & 31.48 & 31.48 & 31.48 \\
Bank Al Habib & 39 & 14.44 & 14.44 & 45.92 \\
Bank Alfalah & 68 & 25.19 & 25.19 & 71.11 \\
Silk Bank & 31 & 11.48 & 11.48 & 82.59 \\
Meezan Bank & 47 & 17.41 & 17.41 & 100 \\
Total & $\mathbf{2 7 0}$ & $\mathbf{1 0 0 . 0}$ & $\mathbf{1 0 0 . 0}$ & \\
\hline
\end{tabular}

The majority of the respondents in the survey (31.48\%) worked for HBL while (25.19\%) worked for Bank Alfalah, (17.41\%) participants worked for Meezan Bank, (14.44\%) for Bank Al-Habib, and $(11.48 \%)$ respondents worked for Silk bank

\begin{tabular}{ccccc} 
Experience & Frequency & Percent & Valid percent & $\begin{array}{c}\text { Cumulative } \\
\text { percent }\end{array}$ \\
\hline Less than 2 years & 35 & 12.96 & 12.96 & 12.96 \\
2-5 years & 73 & 27.04 & 27.04 & 40 \\
6-10 years & 83 & 30.74 & 30.74 & 70.74 \\
Above 10 years & 79 & 29.26 & 29.26 & 100.0 \\
Total & 270 & 100.0 & 100.0 & \\
\hline
\end{tabular}

As shown above, $30.74 \%$ of participants have worked in the banking sector for 6-10 years, and $29.26 \%$ have worked for more than ten years. $27.04 \%$ have worked for $2-5$ years, while the remaining $12.96 \%$ have worked for even less than 2 years.

Reliability Analysis

\begin{tabular}{cc} 
Variables & Cronbach's Alpha Coefficient $(\boldsymbol{\alpha})$ \\
\hline Training & 0.893 \\
Goal Setting & 0.890 \\
Employee Engagement and Commitment & 0.862
\end{tabular}

To assess the reliability of the scale, (Garver \& Mentzer, 1999) strongly advise computing Cronbach's alpha value, if the value is greater than or equal to 0.70 implying sufficient 
reliability. For fundamental research, (Nunnally \& Bernstein, 1968) suggest higher values than 0.80. The alpha scores for the scales of training, goal setting, employee engagement, and commitment are 0.893, 0.890, and 0.862, respectively. The scales used in the research are reliable.

Correlation Analysis

\begin{tabular}{|c|c|c|c|c|}
\hline Variables & & Training & $\begin{array}{c}\text { Goal } \\
\text { Setting }\end{array}$ & $\begin{array}{c}\text { Employee Engagement and } \\
\text { Commitment }\end{array}$ \\
\hline Training & $\begin{array}{c}\text { Pearson } \\
\text { correlation } \\
\text { Sig.(2-tailed) } \\
\mathrm{N}\end{array}$ & 1 & & \\
\hline Goal Setting & $\begin{array}{c}\text { Pearson } \\
\text { correlation } \\
\text { Sig.(2-tailed) } \\
\mathrm{N}\end{array}$ & $.494 * *$ & 1 & \\
\hline $\begin{array}{c}\text { Employee } \\
\text { Engagement and } \\
\text { Commitment }\end{array}$ & $\begin{array}{c}\text { Pearson } \\
\text { correlation } \\
\text { Sig.(2-tailed) } \\
\mathrm{N}\end{array}$ & $.596 * *$ & $.666^{* *}$ & 1 \\
\hline
\end{tabular}

The link between training and employees' engagement and commitment is tested. The finding shows a positive and significant relationship between the independent and dependent variables $(\mathrm{r}$ $=.596^{* *}$, p-value. 05). Likewise, the link between goal setting and employee engagement and commitment is examined. The findings indicate a strong positive correlation between these variables $\left(r=.666^{* *}\right.$, $p$-value. 05$)$.

\section{Regression Analysis}

\begin{tabular}{cccc}
\hline Dependent variable & & \multicolumn{2}{c}{ Employee Engagement and Commitment } \\
\hline Independent variables & R square & Beta $(\boldsymbol{B})$ & Significance \\
\hline Training & 0.355 & 0.727 & 0.000 \\
Goal Setting & 0.444 & 0.993 & 0.000
\end{tabular}

The figure of R-square 0.355 demonstrates a training impact of roughly $36 \%$ on employee engagement and commitment. Where beta coefficient shows 1-unit variations to cause explanatory variable 0.727 changes to the variable response. R-square value 0.444 reflects the impact of goal setting on employee engagement and commitment that is $44 \%$ and beta coefficient indicates a change in an explanatory variable in 1 unit causing the change in the dependent variables to a change of 0.993 . The value of the significance is 0.000 , which is less than a value acceptable $(<.05)$.

\section{Discussion}

We investigated the relationship between training, goal setting, and employee engagement, and commitment in this research. Therefore, we used a questionnaire to collect data from employees working in the banking sector in Hyderabad, Pakistan. The analysis results enabled us to justify the established hypotheses and comprehend the relationship among different variables of the Employee Engagement and Commitment Model. In the subsequent paragraph, we will analyze 
these findings and their implications separately. Previous research has validated the impact of Training Programs on Employee Engagement and Commitment. Employee engagement and dedication at the Workplace are usually a symptom of an employee's cooperation and connection with an organization. According to statistical studies, the more training employers offer, the more committed the employee is to the organization. Whenever an organization provides training to workers, the chances of improvement in performance increase (Abraham, 2012; Fleetwood \& Hesketh, 2006). To be more specific, workers are more willing to hold higher value on training that is widely used and highly regarded by co-workers, managers, and team leaders. According to Bartlett (2001), organizations that can develop a culture in which individuals encourage and value training will be likely to have higher levels of commitment. According to the research results, there is indeed a significant positive relationship between training programs and employees' commitment (Brum, 2007; Millar, 2012).

According to our research findings, there is a significant relationship between training, goal setting and employee engagement and commitment. Levels of dedication can influence how much an employee values his or her job and, as a result, how often they are inclined to use their abilities and skills. Employees with high organizational commitment realized that training at a company is important to them, so they're more likely to agree with the company's core values, perceive a part of the business, be ascertained in assigned tasks, and find job history impactful for the success of the company as well as for themselves, whereas disinterested workers may not (Ahmad et al., 2019; Jaworski et al., 2018; Shoaib \& Kohli, 2017). According to (Berens, 2013) employee, engagement and commitment is an impactful source of motivation for improving employees' vitality levels and encouraging them to continue to work even in tough circumstances.

\section{Conclusion and Suggestion}

The analysis of data reveals that employee engagement and commitment can be accomplished by positively correlating employee training and goal setting and the outcomes could only be obtained by effectively implementing all of the aspects. Information that endorses our hypothesized relationships demonstrates the need to match these variables to create a positive contribution inside the organizational mechanism to boost and improve employee engagement and commitment. By providing employees effective training and goals setting support, management and supervisors can involve their workers in moral commitment and employee engagement. With such behaviour, employees will improve their performance and achieve organizational goals. There is comparatively large and diverse evidence to support the research methods for structural equations. Scales of the study were evaluated as valid and reliable. The evaluation and structural models are both in accordance with information to support all hypotheses in the research. This leads to a conclusion that training and goal setting leads to engaged and committed staff; dedicated staff show greater productivity in their job.

\section{Future Direction}

Researchers in the future should try to find and explore alternative ways to evaluate these constructs. Goal setting, employee engagement, and optimistic behaviour of workers, in the company, can be investigated in several other aspects by emphasizing consequences such as 
disengagement, absenteeism employee behaviour, and career satisfaction as the future path for studies. Additional studies should also attempt to investigate particularly such variables or constructs for the implementation process at the management level by showcasing more detailed information on all these frameworks.

\section{Acknowledgments}

I would like to thank correspondence author Prof. Zhang Zengtian for his assistance throughout this study.

\section{Conflict of Interests}

The authors declare no conflict of interest.

\section{Funding}

For this research work, the authors did not receive funds from any organization.

\section{References}

Abraham, S. (2012). Development of employee engagement programme on the basis of employee satisfaction survey. Journal of Economic Development, Management, IT, Finance, and Marketing, 4(1), 27.

Ahmad, A., Kura, K. M., Bibi, P., \& Khalid, N. (2019). Effet of compensation, traning and development and nanager support on commitment: The moderating effect of co-worker support. RISUS - Journal on Innovation and Sustainability, 10(2), 39-55.

Al-Emadi, M. A. S., \& Marquardt, M. J. (2007). Relationship between employees' beliefs regarding training benefits and employees' organizational commitment in a petroleum company in the State of Qatar. International Journal of Training and Development, 11(1), 49-70.

Alamri, M. S., \& Al-duhaim, T. I. (2017). Employees Perception of Training and Its Relationship with Organizational Commitment among the Employees Working at Saudi Industrial Development Fund. International Journal of Business Administration, 8(2), 2539. https://doi.org/10.5430/ijba.v8n2p25

Ali, H., Nosheen, F., \& Tayyaba, N. (2021). The Impact of Training, Development and Performance on Employees' Performance in the Banking Sector of Pakistan. Pakistan Social Sciences Review, 5(I), 1068-1080. https://doi.org/10.35484/pssr.2021(5-i)81

Ashraf, Z., Jaffri, A., Sharif, M., \& Khan, A. (2012). Increasing Employee Organizational Commitment by Correlating Goal Setting, Employee Engagement and Optimism at Workplace. European Journal of Business, 4(2), 71-77. http://iiste.org/Journals/index.php/EJBM/article/view/1036

Avery, D. R., McKay, P. F., \& Wilson, D. C. (2007). Engaging the Aging Workforce: The Relationship Between Perceived Age Similarity, Satisfaction With Coworkers, and Employee Engagement. Journal of Applied Psychology, 92(6), 1542-1556. https://doi.org/10.1037/0021-9010.92.6.1542

Berens, R. (2013). The Roots of Employee Engagement-A Strategic Approach. Employment Relations Today, 40(3), 43-49. https://doi.org/10.1002/ert

Bolman, L. G., \& Deal, T. E. (2014). How great leaders think: the art of reframing. Wiley. https://www.wiley.com/en-us/How+Great+Leaders+Think\%3A+The+Art+of+Reframingp-9781118140987

Bulut, C., \& Culha, O. (2010). The effects of organizational training on organizational commitment. International Journal of Training and Development, 14(4), 309-322. https://doi.org/10.1111/j.1468-2419.2010.00360.x 
Butler, S. S., Brennan-Ing, M., Wardamasky, S., \& Ashley, A. (2014). Determinants of longer job tenure among home care aides: What makes some stay on the job while others leave? Journal of Applied $\quad$ Gerontology, 33(2), 164-188. https://doi.org/10.1177/0733464813495958

Buttner, E. H., Lowe, K. B., \& Billings-Harris, L. (2012). An Empirical Test of Diversity Climate Dimensionality and Relative Effects on Employee of Color Outcomes. Journal of Business Ethics, 110(3), 247-258. https://doi.org/10.1007/s10551-011-1179-0

Brum, S. (2007). What impact does training have on employee commitmrnt and employee turnover? University of Rhode Island. Seminar Research Paper Series, 1-13.

Cropanzano, R., \& Mitchell, M. S. (2005). Social exchange theory: An Interdisciplinary review. Journal of Management, 31(6), 874-900. https://doi.org/10.1177/0149206305279602

Ehrhardt, K., Miller, J. S., Freeman, S. J., \& Hom, P. W. (2011). An Examination of the Relationship Between Training Comprehensiveness and Organizational Commitment: Further Exploration of Training Perceptions and Employee Attitudes. Human Resource Development Quartely, 22(4), 459. https://doi.org/10.1002/hrdq

Eisenberger, R., Armeli, S., Rexwinkel, B., Lynch, P. D., \& Rhoades, L. (2001). Reciprocation of perceived organizational support. Journal of Applied Psychology, 86(1), 42-51. https://doi.org/10.1037/0021-9010.86.1.42

Festing, M., \& Schäfer, L. (2014). Generational challenges to talent management: A framework for talent retention based on the psychological-contract perspective. Journal of World Business, 49(2), 262-271. https://doi.org/10.1016/j.jwb.2013.11.010

Fleetwood, S., \& Hesketh, A. (2006). HRM-performance research: Under-theorized and lacking explanatory power. International Journal of Human Resource Management, 17(12), 19771993. https://doi.org/10.1080/09585190601041026

Fullagar, C. J., \& Mills, M. J. (2008). Motivation and Flow: Toward an Understanding of the Dynamics of the Relation in Architecture Students. The Journal of Psycholog, 142(March), 533-553.

Garver, M. S., \& Mentzer, J. T. (1999). Logistics Research Methods: Employing Structural Equation Modeling To Test for Construct Validity. Journal of Business Logistics, 20(1), 33-57. https://doi.org/10.1002/(ISSN)2158-1592

Gubman, E. (2004). From Engagement to Passion for Work: The Search for the Missing Person. Human Resource Planning, 27(3), 42-46. http://search.ebscohost.com/login.aspx?direct=true\&db=buh\&AN=14659824\&lang=de\&sit e=ehost-live

Hanaysha, J. (2016). Examining the Effects of Employee Empowerment, Teamwork, and Employee Training on Organizational Commitment. Procedia - Social and Behavioral Sciences, 229, 298-306. https://doi.org/10.1016/j.sbspro.2016.07.140

Hayes, T. M. (2015). Demographic Characteristics Predicting Employee Turnover Intentions. (Doctoral Dissertation). Available from ProQuest Dissertation and Theses Database.

Hazra, K., Ghosh, D. P., \& Sengupta, P. (Dr. . P. P. (2017). Importance of Training and Development and its Impact on Employees' of Hotels in Kolkata, India: An empirical study. Journal of Tourism and Hospitality Management, 5(2), 23-33. https://doi.org/10.15640/jthm.v5n2a3

Irefin, P., \& Mechanic, M. A. (2014). Effect of Employee Commitment on Organizational Performance in Coca Cola Nigeria Limited Maiduguri, Borno State. IOSR Journal of Humanities and Social Science, 19(3), 33-41. https://doi.org/10.9790/0837-19313341

Jaworski, C., Ravichandran, S., Karpinski, A. C., \& Singh, S. (2018). The effects of training satisfaction, employee benefits, and incentives on part-time employees' commitment.

International Journal of Hospitality Management, 74(October 2017), 1-12. https://doi.org/10.1016/j.ijhm.2018.02.011 
Khushk, A. A. (2020). Impact of training,mood and motivation on employee performance in Universities of Sindh,Pakistan. Journal of Management Info, 7(4), 219-231.

Knight, D., Durham, C. C., \& Locke, E. A. (2001). The relationship of team goals, incentives, and efficacy to strategic risk, tactical implementation, and performance. Academy of Management Journal, 44(2), 326-338. https://doi.org/10.2307/3069459

La Guardia, J. G. (2009). Developing who i am: A self-determination theory approach to the establishment of healthy identities. Educational Psychologist, 44(2), 90-104. https://doi.org/10.1080/00461520902832350

Martin, H. J. (2010). Improving Training Impact Through Effective Follow-Up : Techniques and Their Application through effective follow-up : techniques and their application. 29, 520534.

Masterson, S. S., Lewis, K., Goldman, B. M., \& Taylor, M. S. (2000). Integrating Justice and Social Exchange: the Differing Effects of Fair Procedures and Treatment on Work Relationships. Academy of Management Journal, 43(4), 738-748. https://doi.org/10.2307/1556364

McBain, R. (2007). The practice of engagement: Research into current employee engagement practice. Strategic HR Review, 6(6), 16-20.

Medlin, B., \& Green, K. W. (2009). Enhancing performance through goal setting, engagement, and optimism. Industrial Management and Data Systems, 109(7), 943-956. https://doi.org/10.1108/02635570910982292

Mello, J. A. (2015). Strategic human resource management. Cengage Learning. https://www.worldcat.org/title/strategic-human-resource-management/oclc/871209919

Millar, G. (2012). Employee engagement - a new paradigm. Human Resource Management International Digest, 20(2), 3-5. https://doi.org/10.1108/09670731211208085

Mishra, K., Boynton, L., \& Mishra, A. (2014). Driving Employee Engagement: The Expanded Role of Internal Communications. International Journal of Business Communication, 51(2), 183 -202. https://doi.org/10.1177/2329488414525399

Mowday, R. T., Steers, R. M., \& Porter, L. W. (1979). The measurement of organizational commitment. Journal of Vocational Behavior, 14(2), 224-247. https://doi.org/10.1016/0041-008X(75)90174-X

Muhammad, I., \& Tanveer, A. (2015). Impact of training \& development on employees' performance in banks of pakistan. European Journal of Training and Development Studies, $3(1), 22-44$.

Newman, A., Thanacoody, R., \& Hui, W. (2011). The impact of employee perceptions of training on organizational commitment and turnover intentions: A study of multinationals in the Chinese service sector. International Journal of Human Resource Management, 22(8), 1765-1787. https://doi.org/10.1080/09585192.2011.565667

Nies, M. A., Hepworth, J. T., Wallston, K. A., \& Kershaw, T. C. (2001). Evaluation of an instrument for assessing behavioral change in sedentary women. Journal of Nursing Scholarship, 33(4), 349-354. https://doi.org/10.1111/j.1547-5069.2001.00349.x

Nkosi, S. M. (2015). Effects of training on employee commitment, retention and performance: A case study of a Local Municipality in South Africa. European Journal of Business and Management, 7(15), 104-109. www.iiste.org

Nunnally, J. C., \& Bernstein, I. H. (1968). Psychometric theory. American Educational Research Journal, 5(3), 431. https://doi.org/10.2307/1161962

Osborne, S., \& Hammoud, M. S. (2017). Effective Employee Engagement in the Workplace. International Journal of Applied Management and Technology, 16(1), 50-67. https://doi.org/10.5590/ijamt.2017.16.1.04

Presslee, A., Vance, T. W., \& Webb, A. (2013). The Effects of Reward Type on Employee Goal Setting, Goal Commitment and Performance. The Accounting Review, 88(5), 1805-1831. 
https://doi.org/10.2139/ssrn.1656517

R. Anitha, \& Kumar, D. M. A. (2016). A Study On The Impact Of Training On Employee Performance In Private Insurance Sector, Coimbatore District. International Journal of Management Research \& Review, 6(8), 1079-1089.

Saber, D. A. (2013). Generational differences of the frontline nursing workforce in relation to job satisfaction: What does the literature reveal? Health Care Manager, 32(4), 329-335. https://doi.org/10.1097/HCM.0b013e3182a9d7ad

Sendawula, K., Nakyejwe Kimuli, S., Bananuka, J., \& Najjemba Muganga, G. (2018). Training, employee engagement and employee performance: Evidence from Uganda's health sector. Cogent Business and Management, 5(1), 1-12. https://doi.org/10.1080/23311975.2018.1470891

Shahid, A., \& Azhar, S. M. (2013). Gaining Employee Commitment: Linking to Organizational $\begin{array}{llll}\text { Effectiveness. Journal of Management } & \text { Research, }\end{array}$ https://doi.org/10.5296/jmr.v5i1.2319

Siddiqui, D. A., \& Sahar, N. (2019). The Impact of Training \& Development and Communication on Employee Engagement - A Study of Banking Sector. Business Management and Strategy, 10(1), 23. https://doi.org/10.5296/bms.v10i1.14592

Shaver, J. M. (2008). Organizational Significance and Impact of Employee Value Proposition. International Conference on Business, Economics, Socio-Culture and Tourism Organization, 6(2), 9-15. https://doi.org/10.1177/1476127008090009

Shoaib, F., \& Kohli, N. (2017). Employee engagement and goal setting theory. Indian Journal of Health \& Wellbeing, 8(8), 877-880.

Sultana, A., Irum, S., Abid, K., \& Nasir Mehmood. (2012). Impact of training on employee performance :A study of telecommunication sector in Pakistan. Interdisciplinary Journal of Contemporary Research in Business, 4(6), 646-661.

Vandenabeele, W. (2014). Explaining Public Service Motivation: The Role of Leadership and Basic Needs Satisfaction. Review of Public Personnel Administration, 34(2), 153-173. https://doi.org/10.1177/0734371X14521458

Webb, A., Jeffrey, S. A., \& Schulz, A. (2010). Factors affecting goal difficulty and performance when employees select their own performance goals: Evidence from the field. Journal of Management Accounting Research, 22(1), 209-232. https://doi.org/10.2308/jmar.2010.22.1.209

Zahra, S., Iram, A., \& Naeem, H. (2014). Employee Training and Its Effect on Employees’ Job Motivation and Commitment: Developing and Proposing a Conceptual Model. IOSR Journal of Business and Management, 16(9), 60-68. https://doi.org/10.9790/487x16916068

Zehra, N. (2015). Impact of Job Rotation on Employee Performance: The Case of Pakistani Banking Industry. RADS, 2(2), 1-12. 